Paweł Zerka

\title{
HISZPAŃSKI RUCH 15-M: TOŻSAMOŚĆ PROJEKTOWA IN STATU NASCENDI
}

\section{Wprowadzenie}

Ruch 15-M od ponad półtora roku nie przestaje zajmować hiszpańskich socjologów, politologów i publicystów. Ponieważ w międzyczasie podobne protesty rozprzestrzeniły się w wielu innych miejscach globu, interesują się nim również zagraniczni komentatorzy. Rośnie przekonanie, że rozwój ruchu ma szansę wywrzeć wpływ nie tylko na miejscową politykę, ale również na kształt nowoczesnej demokracji en general. Dlatego „zrozumienie” Ruchu 15-M stało się pilną potrzebą chwili. W niniejszym opracowaniu czynimy krok w tym kierunku, śledząc rozwój jego tożsamości zbiorowej.

Ruch 15-M od początku wzbudzał kontrowersje. Jedni mówili o początkach rewolucji, inni zaś o zwykłym ruchu niezadowolenia. Jedni wskazywali na projekt polityczny leżący u podstaw ruchu, inni twierdzili, że jest on luźną zbieraniną osób, które łączy jedynie zniecierpliwienie kryzysem. Pierwsi dawali ruchowi szansę na trwałe zagnieżdżenie się w przestrzeni publicznej, drudzy uznawali go za zjawisko przejściowe, a nawet swego rodzaju karnawał, happening lub festyn, który nieprzypadkowo zbiegł się ze studenckimi wakacjami.

Analiza Ruchu 15-M zaprezentowana w niniejszym opracowaniu wskazuje na ewolucyjny jego charakter. O ile trudno rozumieć dosłownie twierdzenia o hiszpańskiej rewolucji, o tyle coraz wyraźniej widać, że 15-M to nie tylko ruch protestu, lecz również rodzący się ruch projektu. W języku, postulatach i działaniu manifestantów uwidacznia się chęć doprowadzenia do głębokiej społecznej przemiany. Ruch 15-M, skupiający przedstawicieli różnorodnych środowisk, z początku mógł wydawać się niespójny, z czasem jednak ujawniła się osobna i wspólna tożsamość jego uczestników, oparta zarówno na wspólnych doświadczeniach, jak i przekonaniach oraz symbolice. Te ostatnie odgrywają szczególnie istotną rolę, zważywszy na to, że Ruch 15-M wydaje się przykładem tzw. nowego ruchu społecznego, opartego nie tyle na podziałach klasowych, ile na wspólnej kulturze i ekspresji symbolicznej. 
Początkowo można było mieć zastrzeżenia, czy to wszystko okaże się wystarczająco silnym spoiwem, aby ruch osiągnął trwałą tożsamość zbiorową. Wydarzenia ostatnich miesięcy udzieliły na tę wątpliwość dwuznacznej odpowiedzi. Z jednej strony, Ruch 15-M, w pierwszym okresie skupiony na proteście i „okupowaniu” placów, przeszedł głęboką przemianę, koncentrując się z czasem na budowie lokalnych sieci i tworzeniu konstruktywnego programu. Istnienie ruchu zdążyło głęboko wryć się w publiczną świadomość, dzięki czemu niepotrzebne stały się już masowe akcje okupowania placów. Z drugiej strony, w przeciwieństwie do tradycyjnych ruchów społecznych, 15-M nie doświadczył instytucjonalizacji sensu stricto. Można się zastanawiać, na ile jest to dowodem jego słabości, na ile zaś świadectwem, że mamy do czynienia $\mathrm{z}$ ruchem zupełnie nowego typu.

Choć manifestanci deklarują apolityczność, w ukształtowaniu się ich tożsamości, paradoksalnie, dużą rolę odegrały wydarzenia polityczne. W przestrzeni publicznej hiszpańscy protestujący zaistnieli na tydzień przed majowymi wyborami samorządowymi, zaś przedterminowe wybory parlamentarne, rozpisane na 20 listopada 2011 roku i w dużej mierze wymuszone spektakularnymi działaniami manifestantów, dały im wyjątkową szansę na utrzymanie dynamiki ruchu. Inną sprzyjającą okolicznością był nadspodziewanie szybki rozwój międzynarodowej sieci protestu, na czele z amerykańskim ruchem Occupy Wall Street, ale obejmującej także studentów z Chile i Kolumbii czy manifestantów z Izraela i Portugalii. Uczestnikom Ruchu 15-M, przejawiającym od początku wyraźne ambicje ekspansjonistyczne, udało się zorganizować w październiku protesty o zasięgu globalnym, które z różnym powodzeniem odbyły się we wszystkich większych miastach świata zachodniego. To, że tygodnik „Times” uznał „protestujących” za „Ludzi Roku 2011”, jest w dużej mierze dziełem Hiszpanów, którzy byli w awangardzie światowego ruchu protestu względem kondycji współczesnej demokracji.

Niniejsze opracowanie powstało w ramach badań statutowych „Tożsamości kulturowe w Europie - ciągłość i zmiana" realizowanych w Katedrze Socjologii SGH. ${ }^{1}$ Podjęte przeze mnie empiryczne badania hiszpańskiego Ruchu M-15 mają charakter eksploracyjno-opisowy, zaś w warstwie eksplanacyjnej, dotyczącej procesu kształtowania się jego tożsamości zbiorowej, odwołuję się do socjologicznych koncepcji tożsamości aktorów społecznych w epoce „późnej nowoczesności” i „społeczeństwa sieci” sformułowanych przez Manuela Castellsa i Anthony Giddensa. W zakończeniu podejmuję próbę nakreślenia dalszych perspektyw Ruchu M-15 w sytuacji braku jego instytucjonalizacji.

\footnotetext{
1 Badania statutowe „Tożsamości kulturowe w Europie - ciągłość i zmiana” (sygn. nr 02/S/ 0008/11) są realizowane od 2011 roku. Ich inicjatorką i kierowniczką jest Elżbieta Firlit z Katedry Socjologii SGH.
} 


\section{Teorie tożsamości zbiorowej}

Ruch 15-M można rozpatrywać jako, z jednej strony, przykład ruchu społecznego (i to nowego typu), z drugiej zaś jako wyraz zmian charakterystycznych dla współczesnego społeczeństwa. Należy wszak pamiętać, że w obu przypadkach mamy do czynienia z zupełnie odmiennymi koncepcjami tożsamości zbiorowej. Mówiąc o ruchu społecznym, stosunkowo łatwo możemy wyodrębnić zbiorowość, której dotyczyć ma analizowana tożsamość, zaś w pozostałych przypadkach jest to niemożliwe. Jak zauważa Z. Bokszański, „należy sądzić, że określenie tożsamość ponowoczesna jest $\mathrm{w}$ istocie skrótowym zapisem sformułowania, które brzmiałoby tak oto: cechy tożsamości typowej jednostki żyjącej w społeczeństwie, które zbliża się swoimi właściwościami do typu idealnego społeczeństwa ponowoczesnego". ${ }^{2}$ Dlatego, analizując tożsamość Ruchu 15-M, będziemy postępować dwutorowo: doszukując się elementów tożsamości typowych dla tego ruchu społecznego oraz identyfikując pośród uczestników ruchu cechy typowe dla zmieniającej się tożsamości współczesnej. Wydaje się to tym bardziej zasadne, że zakwalifikowanie 15-M do kategorii ruchów społecznych wcale nie jest oczywiste; można wręcz pokusić się o stwierdzenie, że nie jest to już ruch, ale nowa kultura.

\subsection{Anthony Giddens i późna nowoczesność}

W dziele pt. Nowoczesność i tożsamość. Ja i społeczeństwo w epoce późnej nowoczesności $i^{3}$ A. Giddens zarysowuje koncepcję tożsamości typowej dla społeczeństwa późnej nowoczesności. Jego zdaniem „w kontekście porządku posttradycyjnego ja staje się refleksyjnym projektem”.4 To oznacza, że „zmiany tożsamościowe wymagają odkrywania i konstruowania w ramach refleksyjnego procesu, w którym przemiana osobista przeplata się ze społeczną"5. Szczególnego znaczenia w społeczeństwie późnej nowoczesności nabiera strategiczne planowanie życia, co jest o tyle paradoksalne, że mierzymy się z rzeczywistością pełną niepewności i ryzyka.

Nie oznacza to, że życie stało się samo w sobie bardziej ryzykowne, niż było wcześniej. Ale szereg charakteryzujących nowoczesność zmian zapewniło temu ryzyku stałe miejsce w codzienności. Jedna z tych zmian polega na „kolonizacji przyszłości”.

2 Z. Bokszański, Tożsamości zbiorowe, Wyd. Nauk. PWN, Warszawa 2005, s. 63-64.

3 A. Giddens, Nowoczesność i tożsamość. Ja i społeczeństwo w epoce późnej nowoczesności, Wyd. Nauk., PWN, Warszawa 2001.

4 Ibidem, s. 47.

5 Ibidem. 
Jednostki szukają coraz większej kontroli nad przyszłością, choćby wówczas, gdy strategicznie planują swoje życie. A to z natury rodzi ryzyko błędu. Inna zmiana dotyczy upowszechnienia się „doświadczenia zapośredniczonego”, co „radykalnie zmienia sens tego, czym jest świat”. ${ }^{6}$ Żyjąc nadal w środowisku lokalnym, jesteśmy wystawieni na oddziaływania globalne, które, czy tego chcemy czy nie, powiększają nasz obszar niepewności i niepokoju.

Giddens zwraca uwagę na znaczenie postępów w globalizacji dla rozwoju tożsamości. Stwierdza, że „w warunkach wysoko rozwiniętej nowoczesności przekształcenia tożsamości i globalizacja stanowią dwa bieguny dialektycznej relacji między lokalnością a globalnością; innymi słowy, zmiany zachodzące w prywatnej sferze życia osobistego są bezpośrednio związane $\mathrm{z}$ ustanawianiem stosunków społecznych na bardzo szeroką skalę”. I dalej: „po raz pierwszy w dziejach ludzkości jaźń i społeczeństwo są ze sobą wzajemnie powiązane w wymiarze globalnym"s. To oznacza, że w przypadku społeczności lokalnych, które jednak są zintegrowane ze światową kulturą, nie sposób już rozpatrywać tożsamości zbiorowej w oderwaniu od kontekstu globalnego: nie tylko $\mathrm{z}$ uwagi na wpływ tego kontekstu na kondycję tych społeczności i na ich samookreślenie się, ale również ze względu na ich coraz częstsze pretensje do uniwersalnego znaczenia podejmowanych działań.

Wreszcie, kluczowe z punktu widzenia analizy tożsamości Ruchu 15-M jest wprowadzenie do problematyki tożsamościowej wymiaru politycznego. Giddens odróżnia politykę emancypacji od polityki życia. Pierwsza z nich, nastawiona na „wyzwolenie jednostek i grup z ograniczeń, które ciążą na ich szansach życiowych”, jest typowa dla społeczeństw nowoczesnych. Jednakże „jej głównym kierunkiem jest od a nie ku”. Tym też różni się od polityki życia, typowej dla społeczeństw późnej nowoczesności. Program polityki życia obejmuje otwarty katalog dziedzin (m.in. ekologię, reprodukcję biologiczną, globalizację), których wspólnym mianownikiem jest doniosłość kryteriów moralnych. Z punktu widzenia analizy Ruchu 15-M istotna jest obecność w tym programie kwestii kapitalizmu i jego przełożenia na dostęp do środków umożliwiających samorealizację. Zagadnienie to może stanowić jeden z kluczy do zrozumienia protestu hiszpańskich indignados.

\footnotetext{
Ibidem, s. 257.

Ibidem, s. 46

Ibidem.

Ibidem, s. 287
} 


\subsection{Manuel Castells i społeczeństwo sieci}

Jak jednak łatwo zrozumieć, manifestanci z hiszpańskich placów odwołują się znacznie częściej do koncepcji swojego rodaka, Manuela Castellsa. Ten stawia hipotezę, iż „to, kto i po co konstruuje tożsamość zbiorową, na ogół w znacznym stopniu determinuje symboliczną treść tej tożsamości i jej znaczenie dla tych, którzy identyfikują się z nią lub umieszczają poza nią,. ${ }^{10}$ Uznając stosunki władzy za decydujący element społecznego kontekstu konstruowania tożsamości, buduje następującą typologię form i źródeł tego procesu. Po pierwsze, możemy mieć do czynienia $\mathrm{z}$ „tożsamością legitymizującą", jeżeli jest ona promowana przez instytucje dominujące w społeczeństwie, co ma na celu rozszerzenie i zracjonalizowanie ich dominacji. Po drugie, występuje „tożsamość oporu”, „wytwarzana przez tych aktorów, którzy znajdują się w gorszym położeniu/warunkach dewaluowanych i/lub stygmatyzowanych przez logikę dominacji, a tym samym budują szańce oporu i przetrwania na podstawie zasad odmiennych od tych, które przenikają instytucje społeczeństwa, lub przeciwstawnych do nich”. ${ }^{11}$ Wreszcie, możemy się zetknąć z "tożsamością projektu”, która „pojawia się, gdy aktorzy społeczni na podstawie dostępnych im materiałów kulturowych budują nową tożsamość, która redefiniuje ich pozycję w społeczeństwie, a czyniąc to, dążą do transformacji całej struktury społecznej”. Granica między dwoma ostatnimi typami bywa trudna do określenia - tym bardziej że „tożsamości, które zaczynają od oporu, mogą wytworzyć projekty”." ${ }^{12}$. Więcej nawet, Castells stwierdza, że „w społeczeństwie sieci tożsamość projektu, jeśli w ogóle powstaje, wyrasta ze wspólnotowego oporu". ${ }^{13}$

Chociaż Castells, podobnie jak Giddens, zwraca uwagę na przemożny wpływ globalizacji na procesy konstruowania tożsamości, wyciąga $\mathrm{z}$ tej obserwacji odmienne wnioski. Stwierdza mianowicie, że „kiedy świat staje się zbyt wielki, by móc go kontrolować, aktorzy społeczni starają się zmniejszyć go z powrotem do swych wymiarów i zasięgu". ${ }^{14}$ To dlatego najbardziej żywiołowe procesy kształtowania się tożsamości zachodzą w mniejszych „komunach”: etnicznych, religijnych, czy też w ramach ruchów miejskich. Te ostatnie, według Castellsa, „stają się znaczącymi źródłami oporu wobec jednostronnej logiki kapitalizmu, etatyzmu i informacjonizmu”,

10 M. Castells, Siła tożsamości, PWN, Warszawa 2009, s. 23.

11 Ibidem.

12 Ibidem, s. 24.

13 Ibidem, s. 26 .

14 Ibidem, s. 73. 
co prowadzi do swoistego paradoksu „coraz bardziej lokalnej polityki w świecie ustrukturyzowanym przez coraz bardziej globalne procesy”. ${ }^{15}$

Czyżby Ruch 15-M, działający przede wszystkim w dużych miastach i okupujący (jako własne) ich główne place, nie był właśnie tego typu ruchem miejskim, działającym, póki co, głównie na zasadzie oporu, ale potencjalnie mogącym przekształcić się w ruch o cechach tożsamości projektowej?

\section{Ruch 15-M: charakterystyka}

\subsection{Geneza}

To, co dziś nazywamy Ruchem 15-M, jest w istocie zjawiskiem o licznych źródłach i inspiracjach. Po pierwsze, wielu młodych Hiszpanów miało za sobą świeże doświadczenie udziału w protestach politycznych oraz ruchach promujących demokrację oddolną. Wiosną 2011 roku zaczęło wśród hiszpańskich studentów wzbierać niezadowolenie z powodu wysokiego bezrobocia, niekorzystnych warunków zatrudnienia oraz cięć budżetowymi w edukacji i związanego z tym wzrostu kosztu studiów. 30 marca tysiące studentów w całym kraju zorganizowało strajk generalny. Jednocześnie w niektórych kręgach studenckich winy za upadek gospodarki zaczęto upatrywać w specyficznym hiszpańskim systemie partyjnym, zdominowanym od początku transformacji demokratycznej przez dwie partie. Dnia 7 kwietnia organizacja „Młodzi bez przyszłości” (Juventud sin futuro) zorganizowała w Madrycie marsz przeciwko kryzysowi, w istocie wymierzony przeciwko duopolowi Partii Popularnej i Partii Socjalistycznej. Do grona niezadowolonych dołączyli internauci z ruchu „Nie głosuj na nich” (No les votes), już wcześniej sprzeciwiający się przegłosowanemu przez te partie prawu ograniczającemu obieg sztuki w internecie (tzw. ley sinde).

Po drugie, młodzi Hiszpanie zaczerpnęli inspirację z wydarzeń zewnętrznych. Wzorowali się na protestach, które w związku z dotkliwymi społecznie konsekwencjami kryzysu finansowego wybuchły najpierw w 2009 roku na Islandii, a na przełomie lat 2010 i 2011 w Grecji. Pośrednio mobilizacji młodzieży sprzyjała także tzw. arabska wiosna ludów, która, począwszy od stycznia 2011 roku, przelała się przez Afrykę Północną i Bliski Wschód, doprowadzając do zmiany reżimów w Tunezji, Egipcie i Libii oraz wybuchu konfliktów wewnętrznych w innych krajach, m.in. Syrii

\footnotetext{
15 Ibidem, s. 69.
} 
i Jemenie. Przewrotom w Tunezji i Egipcie towarzyszyło wykorzystanie internetowych mediów społecznościowych, takich jak Facebook i Twitter. Rozwiązanie to zostało zaadaptowane przez hiszpańskich studentów do usprawnienia komunikacji i zapewnienia szerokiej mobilizacji.

Wreszcie, po trzecie, podwalin intelektualnych Ruchowi 15-M dostarczył Stephen Hessel, francuski pisarz i dyplomata, autor manifestu „Oburzcie się!” (Indignez-vous!), w którym namawia młodzież do pokojowego powstania „przeciwko massmediom, których horyzonty zamykają się na tym, co poddaje się konsumpcji masowej; przeciwko pogardzie wobec najsłabszych i względem kultury; przeciwko powszechnej amnezji i wyścigowi szczurów". ${ }^{16}$ Broszura autorstwa Hessela stała się prawdziwą „biblią" protestujących, dlatego przez pierwsze tygodnie, dopóki nie ukonstytuowało się określenie Ruch 15-M, nazywano ich przeważnie „oburzonymi” (indignados).

\subsection{Kalendarium}

Katalizatorem społecznej mobilizacji młodych Hiszpanów był wybuch głębokiego kryzysu finansowego, jednak bezpośrednim pretekstem do protestów stały się wybory samorządowe, zaplanowane na 22 maja 2011 roku. Na tydzień przed wyborami, za pośrednictwem platformy internetowej „Prawdziwa demokracja od zaraz!” (Democracia Real Ya!), powstałej na początku 2011 roku i skupiającej szereg pomniejszych organizacji zabiegających o odnowę hiszpańskiej demokracji, zwołano manifestację, która miała się odbyć jednocześnie we wszystkich większych miastach kraju.

Liczba uczestników przerosła najśmielsze oczekiwania organizatorów: w Madrycie na ulice wyszło 20-25 tys. protestujących, w Saragossie - 15 tys., a w Barcelonie - według różnych źródeł - między 6 a 15 tys. Sto osób zdecydowało się pozostać na noc na madryckim placu Puerta del Sol, lecz ich protest został nad ranem przerwany przez policję, która zatrzymała 19 osób. To podziałało na manifestantów niczym płachta na byka. Jeszcze tego samego dnia 10 tys. osób wznowiło protest na Puerta del Sol, rozstawiając namioty i tworząc swego rodzaju „miasteczko” (acampada del sol). Podjęto decyzję o zajęciu placu co najmniej do dnia wyborów. Podobne, choć mniejsze „miasteczka” zaczęly spontanicznie powstawać na głównych placach innych hiszpańskich miast. 18 maja madrycka junta wyborcza orzekła, że manifestacje zakłócają porządek przedwyborczy. Mimo to protestujący pozostali na miejscu. Kulminacyjnym momentem ich mobilizacji były piątek i sobota 20-21 maja 2011

16 S. Hessel, Indignez-vous!, Indigène éditions, Paris 2010. 
roku. Wówczas to, mimo obaw o interwencję policji w związku ze złamaniem prawa wyborczego, w centrum Madrytu, Barcelony, Malagi i Walencji zebrało się po kilkanaście tysięcy manifestantów. Protesty trwały także w innych miastach w kraju i, na znacznie mniejszą skalę, zagranicą - w miastach o licznej mniejszości hiszpańskiej (m.in. w Brukseli, Londynie, Lizbonie i Amsterdamie).

Po wyborach samorządowych 22 maja 2011 roku, w których klęskę ponieśli rządzący Hiszpanią socjaliści, manifestanci z większości miast rozeszli się. Jednak na Puerta del Sol oraz w kilku innych miastach kraju podjęto decyzję o utrzymaniu „miasteczek” przez co najmniej kolejny tydzień, by przez ten czas określić cele i propozycje ruchu oraz wyposażyć go w mechanizmy wewnętrznej koordynacji. W dniu 26 maja 2011 roku na Puerta del Sol odbyło się "zgromadzenie ogólne”, podczas którego przyjęto „konsensus minimum” uwzględniający cztery postulaty: reformy prawa wyborczego, walki z korupcją, efektywnego podziału władz oraz stworzenia mechanizmów kontroli obywatelskiej. Brak postulatów natury ekonomicznej wynikał z wyraźnych podziałów ideologicznych w tym względzie pomiędzy uczestnikami protestu.

Nazajutrz, w związku ze zbliżającym się finałem Ligi Mistrzów, w którym spodziewano się zwycięstwa zespołu FC Barcelona, policja siłą rozpędziła manifestację na Plaza de Cataluña w Barcelonie. To na nowo zmobilizowało protestujących na okupowanych placach innych miast. W sobotę 28 maja manifestanci z Puerta del Sol rozeszli się po osiedlach i dzielnicach, by na mniejszych zebraniach zebrać opinie na temat przyszłości ruchu. Następnego dnia w Madrycie i Barcelonie podjęto decyzję o bezterminowej kontynuacji protestów. Platforma Democracia Real Ya! zapowiedziała organizację manifestacji o zasięgu globalnym w dniu 15 października 2011 roku.

Na początku czerwca przedstawiciele manifestantów z całego kraju spotkali się na Puerta del Sol w celu skoordynowania działań. Podjęto decyzję o zorganizowaniu protestów 11 czerwca, czyli w dniu, gdy nowo wybrane władze miast miały objąć funkcje, oraz o ogólnonarodowych manifestacjach w dniu 19 lipca. Taka perspektywa pozwoliła na stopniowy demontaż „miasteczek”, już bez obaw o przetrwanie ruchu. Dnia 15 czerwca w Barcelonie między policją a manifestantami doszło do starć, które na chwilę zakwestionowały pokojowy charakter Ruchu 15-M. Democracia Real Ya! natychmiast zdystansowała się od tego sposobu prowadzenia protestów.

W lipcu doszło jeszcze do dwóch ważnych wydarzeń, które pozwoliły Ruchowi 15-M zachować impet. Zgodnie z wcześniejszym postanowieniem 19 lipca w całym kraju zorganizowano protesty przeciwko przyjętemu w Brukseli „paktowi euro”. Zgromadziły one więcej uczestników niż te z połowy maja: według niektórych źródeł nawet 250 tys. osób. W ciągu następnych dni z 16 miast Hiszpanii wyruszyły 
w kierunku stolicy „marsze niezadowolonych”, które spotkały się w Madrycie 23 lipca. Wówczas zbudowano na nowo prowizoryczne „miasteczko” na Paseo del Prado, następnego dnia zorganizowano spektakularny marsz pod hasłem „To nie kryzys, tylko system!”, a dzień później odbyło się „I Forum Społeczne 15-M”, podczas którego amerykański noblista Joseph Stiglitz wyraził poparcie dla młodych Hiszpanów.

Początek sierpnia upłynął pod znakiem starć między manifestantami w Madrycie a policją, która nie pozwalała im na ponowne zajęcie Puerta del Sol. Później działania Ruchu 15-M stały się mniej widoczne i polegały głównie na organizacji osiedlowych zebrań oraz przygotowywaniu gruntu pod ogólnoświatową mobilizację, która z powodzeniem odbyła się 15 października 2011 roku. W listopadzie socjaliści ponieśli największą od czasów demokratycznej transformacji klęskę w wyborach parlamentarnych - w znacznej mierze dlatego, że odwrócili się od nich młodzi Hiszpanie. W tym czasie Ruch 15-M koncentruje się na pracy lokalnej w "grupach roboczych”, sporadycznie organizując bardziej spektakularne akcje.

\subsection{Pierwsze interpretacje}

Hiszpańscy socjolodzy, politolodzy i publicyści mieli problem z „zaszufladkowaniem” Ruchu 15-M. Doszukując się przyczyn jego powstania, z reguły wskazywali na bieżący kontekst ekonomiczny. Nie brakowało jednak innych głosów, zwracających uwagę na kulturowy, społeczny i historyczny bagaż Hiszpanii, na popularność idei lewicowych i alterglobalistycznych wśród miejscowej młodzieży lub na ich coraz częstsze przekonanie o potrzebie odnowy nowoczesnej demokracji. ${ }^{17}$

Kwestie ekonomiczne posłużyły bez wątpienia za jeden $\mathrm{z}$ katalizatorów niezadowolenia. Młodzi Hiszpanie od kilku lat borykają się z problemem niskich pensji i braku zatrudnienia, a obecny kryzys finansowy przyczynił się jedynie do ich pogłębienia. Już w 2005 roku trwała w Hiszpanii dyskusja na temat „pokolenia tysiąca euro". ${ }^{18}$ Mianem mileuristas określano młodych i wykształconych, którzy nie byli w stanie znaleźć pracy dającej im więcej niż tysiąc euro miesięcznie. Kryzys finansowy pogorszył tę i tak trudną sytuację ludzi młodych, wielu z nich pozbawiając jakiejkolwiek możliwości pracy. Ogólna stopa bezrobocia wynosi obecnie ponad $20 \%$, a wśród młodego pokolenia sięga $43 \%$. Ich frustrację pogłębiają czynniki psychologiczne: hiszpańskiej młodzieży od małego wpajano, że są złotym pokoleniem, rozwijającym się nareszcie w czasach demokracji, pokoju i prosperity. Wydawali się skazani na sukces, tymczasem czekało ich wyjątkowo twarde lądowanie.

17 P. Zerka, Hiszpania podpala Europe, demosEUROPA-Centrum Strategii Europejskiej, 21.05.2011.

18 A. Jimenez Barca, La generación de los mil euros, „El Pais” 23.10.2005. 
Ale manifestacje prawdopodobnie nie byłyby równie liczne, gdyby nie bieżący kontekst polityczny - zarówno w Hiszpanii, jak i w Europie. W obu przypadkach na pierwszy plan wybija się dyskusja na temat jakości demokracji. ${ }^{19}$ Po pierwsze, zniecierpliwienie protestujących budzi dominacja na krajowej scenie politycznej dwóch partii, niezdolnych ich zdaniem do poradzenia sobie z kryzysem finansowym i do ograniczenia skali korupcji. Nieprzypadkowo kwestie odnowy demokracji znajdują uprzywilejowane miejsce $\mathrm{w}$ ich postulatach. ${ }^{20}$ Wyjątkowej okazji do zaprezentowania ich haseł w przestrzeni publicznej dostarczyły im wybory samorządowe z maja 2011 roku, a także przedterminowe wybory parlamentarne rozpisane w listopadzie. Po drugie, frustrację młodych Hiszpanów pogłębia niejasny dla nich podział władzy pomiędzy poziomem krajowym i europejskim, co znajduje odzwierciedlenie w coraz bardziej ponadnarodowym charakterze ich haseł i działań. Ich zniecierpliwienie można zrozumieć: kryzys zadłużeniowy skazał kraje południa Europy na łaskę i niełaskę innych członków tej strefy oraz zagranicznych instytucji finansowych. Debata o ratowaniu peryferyjnych gospodarek eurozony toczy się w dużej mierze za ich plecami, głównie w Brukseli i we Frankfurcie, a prym wiodą w niej główni architekci wspólnej przestrzeni monetarnej, czyli Niemcy i Francuzi. Nie jest zatem przypadkiem, że młodzi Hiszpanie czują się awangardą przemiany polityki europejskiej jako takiej, pilnie wymagającej odbudowy społecznej legitymacji.

Wśród pierwszych komentarzy na temat Ruchu 15-M zwracano również uwagę na kwestie o charakterze historycznym, kulturowym i społecznym. Wskazywano m.in. na hiszpańskie problemy z tożsamością narodową, przejawiające się chociażby w dążeniach niepodległościowych Basków i Katalończyków; ostrych podziałach ideologicznych pozostawionych po wojnie domowej 1936-1939 i czasach dyktatury generała Franco (1936-1975), czy też sporem między zwolennikami monarchii i republiki. Manifestanci w pierwszych dniach dostarczyli powodów do takiej interpretacji: pośród haseł, jakie można było usłyszeć na madryckim Puerta del Sol, przewijał się apel o zerwanie z monarchią i ustanowienie trzeciej republiki, o zdecydowane rozdzielenie Kościoła od państwa i o potępienie frankizmu. Protesty mogły być zatem interpretowane jako wyraz traumy historycznej, której doświadczają młodzi Hiszpanie. Jednakże rozwój Ruchu 15-M skłania do zakwestionowania tej hipotezy, zważywszy na stopniową marginalizację haseł historycznych, a uwypuklenie postulatów dotyczących bieżącej polityki i spraw gospodarczych.

Istotną rolę może natomiast odgrywać kwestia tożsamości Hiszpanów jako Europejczyków. Hiszpanie przez ostatnie dwadzieścia kilka lat żyli integracją europejską,

19 P. Zerka, Jak trwoga, to do demokracji!, demosEUROPA-Centrum Strategii Europejskiej, 9.06.2011.

20 P. Zerka, Po dwóch stronach demokracji, demosEUROPA-Centrum Strategii Europejskiej, 4.07.2011. 
dzięki której i kraj, i społeczeństwo doświadczyły głębokiej modernizacji. Do niedawna byli prymusami Unii Europejskiej, umiejętnie korzystającymi z funduszy wspólnotowych i nader szybko integrującymi się ze „starą" Europą. Wydaje się, że ów sukces gospodarczy i polityczny przyćmił na chwilę myślenie o przeszłości. Jedność narodowa budowana była w oparciu o świetlaną przyszłość, podczas gdy np. rany po wojnie domowej pozostawały niezabliźnione. Dopiero kryzys gospodarczy na nowo zepchnął Półwysep Iberyjski na peryferie Europy. Hiszpanie mogą czuć się upokorzeni tym, że Unia patrzy na nich jak na kolejną Grecję. To z kolei budzi wśród nich zrozumiałe poczucie dziejowej niesprawiedliwości, a zarazem stawia pod znakiem zapytania ich "nową" tożsamość, wciągając z powrotem na agendę problemy z tą "starą". Z tej perspektywy wybuch protestów można by odczytywać jako zdystansowanie się młodych Hiszpanów wobec skorumpowanej i nieudolnej (w ich przekonaniu) klasy politycznej, czy też jako próbę uratowania swojej dotąd przychylnej opinii w Europie poprzez zademonstrowanie umiejętności zorganizowania się i walki o jakość demokracji. Za taką interpretacją przemawiałoby powtarzające się podczas manifestacji przedstawianie Hiszpanii jako europejskiej awangardy oraz starannie przygotowana organizacja jesiennego protestu o zasięgu globalnym.

Inni komentatorzy wskazywali na lewicowe sympatie demonstrantów. Przykładowo, prof. Ramón Cotarelo z madryckiego Universidad Complutense stwierdził: „mamy do czynienia z ruchem czysto lewicowym. Jego postulaty są typowe dla lewicy, sęk w tym, że politycy lewicowi często o nich zapominają.". stoi w sprzeczności z deklaracjami uczestników ruchu. O ile większa część młodych Hiszpanów faktycznie podziela idee lewicowe, a ruch alterglobalistyczny jest w tym kraju silnie rozwinięty, to specyfika 15-M polega na tym, że - wręcz przeciwnie łączy on osoby sympatyzujące zarówno z lewicą, jak i z prawicą. Jednym z pierwszych haseł, które zrobiły furorę podczas protestów, dokładając kolejną cegiełkę do kształtującej się tożsamości ruchu, było „Nie popieramy nikogo” (Ninguna bandera). To z kolei stawia ten ruch w opozycji do ideologicznie zadeklarowanych i zaangażowanych studentów z „Maja ‘68” czy wobec alterglobalistów, najbardziej aktywnych w pierwszych latach XXI wieku. ${ }^{22}$ Ponieważ Ruch 15-M łączy różne środowiska, nieuniknione jest pojawianie się na organizowanych przezeń zgromadzeniach propozycji skrajnie lewicowych i demagogicznych, np. obalenia obecnego systemu kapitalistycznego. Niemniej to nie one definiują kierunek działania ruchu. Można wręcz się zastanawiać, w jakim stopniu przedstawianie „oburzonych” jako lewicowców

21 Indignados espanoles: su identidad, y su futuro en juego, „La Vanguardia” 27.06.2011.

22 M. Serra, 15M: formas generacionales y pasiones colectivas, [referat wygłoszony 31.05.2011 podczas konferencji „15-M: la construcction del acontecimiento” na Universidad Complutense w Madrycie]. 
i anarchistów służyło niektórym mediom lub przedstawicielom establishmentu do zdyskredytowania ruchu.

To wcale nie oznacza, że protestanci są nieskazitelnymi ideowcami. Już na samym początku protestów dało się słyszeć, w pewnej mierze uzasadnione, głosy, że mamy do czynienia ze studenckim „karnawałem”. Felix Ortega, socjolog z Uniwersytetu Complutense, twierdził: „Dostrzegam w tym coś w rodzaju happeningu; nocnej zabawy, która trwa do białego rana. [...] Przypomina mi to protesty przeciwko reformie bolońskiej”. ${ }^{23}$ Faktycznie, trudno uniknąć wrażenia, że wiele młodych osób traktowało udział w protestach i okupowanie placów jako wakacyjną atrakcję; kolejną tak uwielbianą przez Hiszpanów fiestę. Należy pamiętać o tym „odbrązowionym” wizerunku 15-M, który może w przyszłości pomóc w wyjaśnieniu ewentualnych problemów z utrzymaniem dynamiki ruchu.

Choć $\mathrm{w}$ różnej proporcji, każdy z wymienionych składników w jakimś stopniu pomaga zrozumieć wybuch protestów w Hiszpanii, prawdopodobnie też każdy znajduje odzwierciedlenie w kształtującej się tożsamości Ruchu 15-M. Jak zauważa M. Castells: „Konstruowanie tożsamości wykorzystuje jako budulec materiały pochodzące $\mathrm{z}$ historii, geografii, biologii, $\mathrm{z}$ instytucji produkcji i reprodukcji, z pamięci zbiorowej i osobistych marzeń, $\mathrm{z}$ aparatów władzy i objawień religijnych. Jednak materiały te są przetwarzane przez jednostki, grupy społeczne i społeczeństwa, a ich znaczenie jest reorganizowane zgodnie ze społecznymi wyznacznikami i projektami kulturowymi, które są zakorzenione w ich strukturze społecznej i ramach przestrzenno-czasowych". ${ }^{24}$ Dlatego kluczowe jest pytanie o to, jakie znaczenie nadaje Ruch 15-M materiałom ekonomicznym, politycznym, historycznym, kulturowym i społecznym, które przyczyniły się do jego powstania i które teraz go definiują. To na tych wspólnych znaczeniach opierać się będzie tożsamość zbiorowa ruchu.

\section{Ruch 15-M: tożsamość projektowa in statu nascendi}

\subsection{Narodziny tożsamości}

W początkowej fazie Ruch 15-M obfitował w sprzeczności, trudno było doszukać się jego jednoznacznej linii, w głoszonych hasłach dominowało niezadowolenie,

\footnotetext{
23 A. Muñoz, De fiesta nocturna a Mayo del 68, „El Pais” 20.05.2011.

24 M. Castells, op.cit., s. 23.
} 
brakowało natomiast wspólnych, wyrazistych i konstruktywnych propozycji. Podczas pierwszych dni manifestacji można było usłyszeć głównie hasła, które wynikały z ekonomicznej frustracji („Praca dla młodych!”, „Większa płaca minimalna!”, „Nie obcinać zasiłków!”, „Skorumpowanych polityków - na galery!”, „Dlaczego rządzi rynek, skoro na niego nie głosowaliśmy?”, „Nie jesteśmy towarem w rękach polityków i bankierów”). Poza tym apelowano o pospolite ruszenie („Hiszpańska rewolucja” i „Niech Hiszpania będzie dumna jak Islandia!”). W wielu przypadkach nawiązywano do terminologii komputerowej („Błąd systemu!”, „Zaktualizować program!”).

Maski Guya Fawkesa (tzw. anonimy), brytyjskiego spiskowca z przełomu XV i XVI wieku, szybko stały się rozpoznawalnym gadżetem wielu protestujących. Obecność „anonimów” od początku hiszpańskich manifestacji świadczyła, z jednej strony, o ważnej roli internetu zarówno w komunikacji, jak i identyfikacji członków ruchu, z drugiej natomiast wskazywała na negatywny wydźwięk protestów, skierowanych "przeciwko" aktualnej rzeczywistości, nieproponujących zaś pozytywnego projektu alternatywnego.

Gdy uczestnicy protestów zaczęli formułować pierwsze postulaty, te sprawiały wrażenie chaotycznych, niespójnych, a nawet wzajemnie sprzecznych. Niektórzy żądali zniesienia „niesprawiedliwych ustaw”, uznając za takie prawo wyborcze czy prawo autorskie. Inni chcieli referendum, podczas którego obywatele wybraliby między monarchią a republiką. Wiele osób apelowało o reformy fiskalne, m.in. obciążenie bogatych wyższymi podatkami, a także o podwyższenie płacy minimalnej. Proponowano cięcia w wydatkach wojskowych i w przywilejach klasy rządzącej. Apelowano o decentralizację polityki poprzez wprowadzenie do niej większej liczby elementów demokracji uczestniczącej. Niektórzy żądali całkowitego oddzielenia Kościoła od państwa. A jeszcze inni zwracali uwagę na potrzebę odnowy pamięci historycznej, do czego potrzebne byłoby ich zdaniem jednoznaczne potępienie frankizmu. ${ }^{25}$

Nie należy zatem się dziwić, że w pierwszych komentarzach na temat 15-M dominowało poczucie, że jest to ruch roszczeniowy, o zabarwieniach lewicowych, mało wiarygodny ze względu na „happeningową” naturę i na tyle słabo skoordynowany, że mający małe szanse przetrwania i wywarcia wpływu na rzeczywistość polityczną. Z czasem jednak zaczęła kształtować się narracja, która pozorne słabości ruchu, takie jak heterogeniczność czy brak liderów, uznała za jego cechy konstytutywne i silne strony. Wspólne doświadczenia pierwszych dni i tygodni manifestacji pomogły w konsolidacji ruchu. Zwłaszcza protesty w przeddzień wyborów samorządowych, zorganizowane mimo sprzeciwu junty wyborczej, odegrały rolę swego rodzaju

25 P. Ortega Dolz, I. Sant Aeulalia, Que quiere Sol?, „El Pais” 20.05.2011. 
„chrztu bojowego”. W sumie Ruch 15-M zaczął nabierać wyraźniejszych kształtów oraz specyficznego etosu i estetyki.

Możliwe też stało się określenie głównych cech definiujących ruch. Trafnie przedstawił je anonimowy uczestnik protestów, ${ }^{26}$ wskazując na sześć głównych elementów. Po pierwsze, dominację ludzi młodych, dla których protesty często stanowią pierwsze doświadczenie z zakresu aktywności politycznej. Po drugie, bezpartyjność, której mimo to towarzyszy silny komponent ideologiczny. Protestujący, niezadowoleni z jakości krajowej polityki, mają się ponoć opowiadać za takimi wartościami, jak uczciwość służby publicznej, sprawiedliwość społeczna, redystrybucja dochodów, przejrzystość zarządzania środkami publicznymi, czy też włączenie obywateli w procesy demokratyczne. Po trzecie, silne osadzenie w bieżącym kontekście ekonomicznym (kryzys finansowy, rządowy program cięć fiskalnych) oraz politycznym (wybory samorządowe, spadek zaufania wobec rządu). Po czwarte, pokojowa natura protestów (non-violence), mających zazwyczaj formę zgromadzeń, w których każdy może zabrać głos. Manifestujący zdecydowanie odcinają się od stosujących przemoc ruchów antysystemowych. Po piąte, wykorzystanie nowoczesnych technologii internetowych, a zwłaszcza sieci społecznościowych (m.in. Facebook i Twitter), co służy nie tylko sprawniejszej komunikacji, ale również spójności działań i ich lepszej organizacji. Wreszcie, po szóste, ruch ma pretensje ekspansjonistyczne, zakładając przejście od wymiaru lokalnego do międzynarodowego.

Oprócz tego uwagę zwraca „horyzontalność” ruchu, polegająca na braku hierarchii, pełnej otwartości wobec nowych członków i jednomyślnego sposobu podejmowania decyzji. Jednomyślność stanowiła barierę dla sprawnego uzgadniania postulatów i to głównie przez nią ruch nie był w stanie przez długi czas uzgodnić jednolitych propozycji ekonomicznych. Niemniej postrzegana była ona jako fundament alternatywnego projektu politycznego, określanego mianem demokracji uczestniczącej. Równie dużą wagę przywiązywano do kwestii braku hierarchii: nawet rzecznicy prasowi protestów na Puerta del Sol zmieniali się codziennie, aby nie doszło do sytuacji, w której ruch kojarzony byłby z konkretnymi osobami.

Ruch zaczął kształtować się wokół koncepcji idealistycznych, by nie rzec utopijnych. Ten idealizm był obecny w wielu najbardziej nośnych hasłach, takich jak „Mamy prawo śnić” albo „Jeżeli nie pozwolicie nam śnić, my nie damy wam spać”. ${ }^{27}$ Dobrze też obrazuje go przykład placu Puerta del Sol jako „świata bez pieniądza”. Wyjątkową atmosferę protestów reporterka „Gazety Wyborczej” skomentowała

26 El movimiento ciudadano del 15M: Apuntes sobre su identidad, http://evoluntas.wordpress.com, 28.06.2011.

27 M. Jesus Casals, 15-M: La construccion del acontecimiento [referat wygłoszony 31.05 .2011 podczas konferencji „,15-M: la construccion del acontecimiento” na Uniwersytecie Complutense w Madrycie]. 
w następujący sposób: „Nikt cię nie sprawdza, nikt niczego od ciebie nie żąda, nie ma pułapek, haczyków. Wszyscy zakładają, że jesteś uczciwy, honorowy i kulturalny. Tak jakbyśmy na pewien czas, dla eksperymentu, zresetowali naszą wiedzę o ludzkiej naturze”. Nazwała też Puerta del Sol „alterświatem”.28

"Miejsce” stało się kluczowym elementem kształtującej się tożsamości Ruchu 15-M. Guillermo Zapata, hiszpański scenarzysta zafascynowany pojawieniem się ruchu, stwierdził, że ten stał się zjawiskiem realnym i nieodwracalnym w momencie, gdy w ciągu jednej nocy skupisko namiotów na Puerta del Sol zmieniło się z kempingu w "miasteczko”, dzięki czemu powstała całkiem nowa przestrzeń. ${ }^{29} \mathrm{Z}$ kolei prof. Raul Magallón z Uniwersytetu Karola II w Madrycie przypomniał o tym, że plac Puerta del Sol zawsze był jednym z najbardziej symbolicznych miejsc w Madrycie. Zwrócił uwagę na hasła kursujące w internecie pomiędzy manifestantami: „Zajmij Plac” (Toma la Plaza) czy „Obozowisko na Sol” (Acampada de Sol), za pomocą których „aktywiści próbowali wziąć przestrzeń publiczną we wspólne posiadanie, pokazując tym samym, że jest ona przestrzenią dostępną dla wszystkich, a nie tylko dla państwa". ${ }^{30}$ Jeżeli niektórzy komentatorzy porównywali wydarzenia w Hiszpanii do tzw. arabskiej wiosny, to nie tylko ze względu na wykorzystanie narzędzi komunikacji internetowej, ale również symboliczne przywiązanie do miejsc. $Z$ tej perspektywy plac Puerta del Sol jawił się jako odpowiednik kairskiego Placu Tahrir - przy czym za centralną rolą „miejsca” w konstrukcji tożsamościowej Ruchu 15-M przemawiają dwa dodatkowe argumenty. Po pierwsze, jednego z pierwszych dni protestów grupa uczestników częściowo zasłoniła nazwę Puerta del Sol, zamiast tego wieszając napis Plaza de Solución - czyli „Plac Rozwiązań”. Po drugie, opuszczając plac po ponad miesięcznej „okupacji”, manifestanci zdecydowali o rozpoczęciu działań w poszczególnych dzielnicach i osiedlach. Zastosowane wówczas hasło „Zajmijmy osiedla" (Toma los barrios) należy odczytywać jako próbę poszerzenia przestrzeni aktywności Ruchu 15-M.

Zarówno przywiązanie do „miejsc”, jak i dominacja młodych mieszkańców miasta w szeregach ruchu potwierdzałyby hipotezę o tym, że mamy do czynienia przede wszystkim z ruchem miejskim - uważanym przez M. Castellsa za jeden z głównych

28 K. Surmiak-Domańska, Bezrobotna Hiszpania. Oburzeni w Bramie Słońca, „Gazeta Wyborcza - Duży Format" 12.06.2011.

29 G. Martinez, El 15-M en el museo, „El Pais” 18.07.2011.

30 R. Magallón, 15-M: del agora audiovisual a la plaza publica, [referat wygłoszony 31.05.2011 podczas konferencji „15-M: la construccion del acontecimiento” na Uniwersytecie Complutense w Madrycie]. 
aktorów zdolnych przeciwstawić się „logice kapitalizmu”. Narodziny Ruchu 15-M potwierdzałyby hipotezę hiszpańskiego socjologa o tym, że „kiedy świat staje się zbyt wielki, by móc go kontrolować, aktorzy społeczni starają się zmniejszyć go z powrotem do swoich wymiarów i zasięgu". ${ }^{31}$ Dramatyczne skutki globalizacji wymuszają lokalność, a sens i tożsamość są wytwarzane na nowo w „mojej dzielnicy”, „mojej społeczności”, „moim mieście”..32

Jedną z głównych przyczyn kryzysu gospodarczego w Hiszpanii była globalizacja finansowa - polegająca $\mathrm{w}$ tym wypadku m.in. na liberalizacji międzynarodowych transakcji finansowych oraz integracji walutowej Hiszpanii ze strefą euro. Ale dodatkowych powodów do niezadowolenia dostarczyła protestującym globalizacja polityczna: integracja $\mathrm{w}$ ramach UE, charakteryzująca się nieczytelnym podziałem kompetencji i władzy pomiędzy poziomem narodowym a europejskim. Odczuwając malejącą kontrolę nad polityką i własną sytuacją ekonomiczną, członkowie Ruchu 15-M starali się przywrócić ład i poczucie wspólnoty, organizując się na poziomie lokalnym i -symbolicznie - tworząc nową przestrzeń: „miasteczka” na głównych placach hiszpańskich miast. Swoją przestrzeń budowali także w internecie, nie tylko porozumiewając się przy użyciu Facebooka i Twittera, ale również uruchamiając alternatywne, niezależne fora dyskusyjne i własną rozgłośnię radiową. Od lat opisywane przez Castellsa społeczeństwo sieci w pełni ziściło się w tej otwartej, horyzontalnej społeczności, kształtującej się za pośrednictwem sieci internetowej i rozwijającej więzi $z$ analogicznymi środowiskami w innych krajach. Warto przypomnieć, że zdaniem Castellsa jednym z głównych podmiotów oporu wobec globalizacji stają się właśnie „usieciowione, zdecentralizowane formy organizacji i interwencji, charakterystyczne dla nowych ruchów społecznych". ${ }^{33}$

Ale najciekawszy wkład w analizę Ruchu 15-M ma wprowadzone przez Castellsa rozróżnienie pomiędzy tożsamością oporu a tożsamością projektu. Ruch 15-M, w swych początkach skupiony na oporze, zaczął z czasem przechodzić transformację w kierunku ruchu opartego na projekcie. Świadczy o tym stopniowe formułowanie głównych postulatów, a także wprowadzanie w życie zasad demokracji uczestniczącej, której elementy chciałby przeszczepić na poziom polityki narodowej, a może nawet europejskiej.

Większość komentatorów skorygowała swoje wstępne zdanie na temat 15-M, uznając go za ruch zdolny do wywołania zmiany w hiszpańskiej polityce i społeczeństwie. Niemniej jest za wcześnie, aby ulegać intuicji Castellsa, który swoje dzieło na temat tożsamości zbiorowych kończy słowami: „Właśnie w tych bocznych zaułkach

31 M. Castells, op.cit., s. 73.

32 Ibidem, s. 69.

33 Ibidem, s. 386. 
społeczeństwa, czy to w alternatywnej elektronicznej sieci, czy w oddolnych sieciach wspólnotowego oporu, wyczuwam zalążki nowego społeczeństwa, wypracowane na polu historii przez siłę tożsamości”. ${ }^{34}$

\subsection{Tożsamość późnej nowoczesności a Ruch 15-M}

Istnieje ciekawa paralela pomiędzy występującym u Castellsa rozróżnieniem tożsamości oporu i tożsamości projektu a typowym dla Giddensa przeciwstawieniem polityki życia polityce emancypacji. Nie są to opozycje tożsame. W przypadku analizy Ruchu 15-M różnica pomiędzy tymi perspektywami sprowadza się do pytania, czy ruch oburzonych wyłonił się w związku ze zmianami, które na przestrzeni wielu lat wystąpiły w hiszpańskim społeczeństwie, czy też wyrósł spod tożsamości głównego nurtu, ukazując przepaść pomiędzy dominującym dyskursem a tożsamością mniejszych wspólnot. Niestety, trudno na to pytanie udzielić konkluzywnej odpowiedzi. Wydaje się, że zjawisko 15-M łączy w sobie obie perspektywy, mając źródło zarówno w przemianach typowych dla późnej nowoczesności, jak i w nasileniu się wspólnotowego oporu w konkretnym kontekście hiszpańskim. A to oznacza, że koncepcje Giddensa i Castellsa są w tym wypadku komplementarne.

Postulaty zgłaszane przez uczestników protestów mogły wydawać się czysto roszczeniowe, ale z czasem uwidoczniło się w nich „drugie dno”, pod wieloma względami zbieżne z programem tego, co Giddens nazywa polityką życia. Nie były to, co prawda, hasła dotyczące cielesności czy potrzeb planetarnych, a zatem tego, co brytyjski socjolog uznaje za jądro tej polityki; ale owszem, protestujący postawili w centrum uwagi kwestie moralno-egzystencjalne związane z rozwojem kapitalizmu, jakością demokracji czy sprawiedliwością społeczną. Z ich protestu zaczęła wyłaniać się coraz bardziej konkretna propozycja odnowy społeczeństwa i państwa. Ta miałaby polegać na m.in.: aktywniejszym włączeniu obywateli do polityki (w duchu demokracji uczestniczącej), zapewnieniu obywatelom większej ochrony przed skutkami rozwoju międzynarodowego kapitalizmu i kontroli nad nim, a także na wzmocnieniu kapitału społecznego wśród obywateli przyzwyczajonych do zasad konkurencji. Dowodem na to, że taki alternatywny porządek może zaistnieć, było sprawnie działające „miasteczko bez pieniądza” na Puerta del Sol. Sam sposób, w jaki zorganizowany jest Ruch 15-M, wskazuje na odmienną koncepcję władzy - która nie powinna być „ponad” obywatelami, lecz „poprzez” obywateli, którzy tym samym powinni mieć możliwość autonomicznego kształtowania swojego losu, zgodnie z Giddensowską koncepcją „życia jako refleksyjnego projektu”.

34 Ibidem, s. 387. 
Hiszpańskie protesty mogą ponadto być rozpatrywane jako przykład dialektycznej relacji pomiędzy globalnością i lokalnością, na którą też zwraca uwagę Giddens. $\mathrm{Z}$ jednej strony wskazują one na lokalne skutki globalizacji. W końcu katalizatorem protestów był kryzys finansowy, który dlatego tak silnie uderzył w Hiszpanię, że należy ona obecnie do najbardziej otwartych gospodarek na świecie. Nieprzypadkowo Ruch 15-M postawił w centrum uwagi kwestię takiego kontrolowania globalizacji, aby nie zaburzała ona perspektyw rozwojowych na poziomie lokalnym, z pozoru oddalonym od zglobalizowanej gospodarki. Zarazem hasła i symbole wykorzystywane przez protestujących (m.in. maski Guya Fawkesa) nawiązywały do manifestacji, które miały wcześniej miejsce w innych częściach świata, wpisując tym samym Ruch 15-M w kontekst globalizującej się kultury i przemian typowych dla wielu społeczeństw.

\section{Tożsamość - i co dalej?}

Koncepcje teoretyczne Castellsa i Giddensa pozwalają lepiej zrozumieć proces kształtowania się tożsamości zbiorowej Ruchu 15-M. Niemniej, jeśli obaj autorzy zwracają uwagę na czynniki warunkujące społeczną mobilizację, to niestety zaniedbują kwestię instytucjonalizacji ruchu. A jest to zagadnienie w przypadku hiszpańskich indignados mocno problematyczne. Z jednej strony ich ruch doświadczył już cząstkowej instytucjonalizacji - stale rozwija się sieć lokalnych zgromadzeń, a jednocześnie koordynowana jest praca tysięcy mikroinstytucji, które wcześniej działały w odosobnieniu. ${ }^{35} \mathrm{Z}$ drugiej zaś wciąż obowiązuje zasada, zgodnie z którą ruch unika jakiejkolwiek hierarchizacji. Czy bez wyraźnego przywództwa możliwe jest utrzymanie dynamiki ruchu w dłuższym okresie?

Aby odpowiedzieć na to pytanie, warto odwołać się do innego teoretyka nowych ruchów społecznych, Alberto Melucciego. Ten przypomina nam, że nowe ruchy społeczne są „społecznymi konstrukcjami w trakcie tworzenia, a nie jednolitymi obiektami empirycznymi”. ${ }^{36}$ Dlatego ich struktura organizacyjna nie musi odzwierciedlać tej, która była typowa dla ruchów społecznych starego typu - rodzących się głównie w środowiskach robotniczych i skupionych na walce klasowej. Odnosząc się

${ }^{35}$ L. Moreno-Caballud, M. Sitrin, The Camp is the World: Connecting the Occupy Movements and The Spanish May 15th Movement, http://takethesquare.net/2011/11/23the-camp-is-the-world-connecting-theoccupy-movements-and-the-spanish-may-15th-movement/

36 S.M. Buechler, Teorie nowych ruchów społecznych, w: Dynamika życia społecznego, red. K. Gorlach, P. Mooney, Scholar, Warszawa 2009, s. 167. 
do kwestii organizacji nowych ruchów, Melucci zauważa, że „działania zbiorowe są najczęściej zagnieżdżone w sieci zanurzonych społecznie grup, okazjonalnie łączących się w samoodnoszące się formy organizacyjne tworzone na potrzeby walki - ale często na zasadach tymczasowych" ${ }^{37}$ Dlatego sugeruje, by zamiast o ruchach mówić o „sieci ruchów” lub „obszarach ruchu”. Czy jest coś złego w tej przejściowej formie współczesnej mobilizacji? Jego zdaniem nie, gdyż ruchy nowego typu są niekoniecznie nastawione na osiągnięcie wymiernych celów strategicznych, a bardziej służą zbiorowej ekspresji symbolicznej.

Z tej perspektywy pytanie o instytucjonalizację Ruchu 15-M, czy o jego ewentualne upartyjnienie, zdaje się obnażać inercję myślenia. Może bowiem być tak, że Ruch 15-M nie potrzebuje żadnej hierarchizacji. Dzięki kilkumiesięcznemu funkcjonowaniu w przestrzeni publicznej zdążył już stać się elementem powszechnej świadomości i tożsamości. Trafnie ujmuje to dwoje weteranów protestów w USA: „Chociaż indignados przestali już okupować place, ich obecność wyczuwalna jest w całej Hiszpanii. Bo oni po prostu stali się kulturą!" ${ }^{38}$ Oczywiście, w takim wypadku coraz trudniej jest nazywać Ruch15-M ruchem społecznym. Ale zarazem nie sposób zaprzeczyć kształtowaniu się nowej zbiorowej tożsamości, i to dalece wykraczającej poza granice Hiszpanii.

\section{Spanish indignados: a project identity in the nascent state}

The Spanish movement of May 15th (15-M) has become a reference point for other groups of indignados, which have emerged in different parts of the world. This is why 15-M has already inspired a number of studies by Spanish and foreign scholars, both in the camp of sociology and in political science. It has also aroused a rising of interest among journalists. In this study, we make a first step towards better understanding of the 15-M movement, by trying to define its group identity.

Our analysis point to an evolutionary nature of the movement. Initially, it was rather chaotic and lacking coherence, but with time it acquired several proper characteristics, among them domination of young people, political indifference, pacifism, as well as a widespread use of new technologies. Besides, while resistance and discontent served as its common ground at the very beginning, after that the movement has bacome an advocate of a specific social change. Its idea of a change

\footnotetext{
37 Ibidem, s. 168.

${ }^{38}$ L. Moreno-Caballud, M. Sitrin, op.cit.
} 
has consisted in the development of partcipatory democracy, in the harnessing of the global capitalism, and in the provision of social justice and adequate conditions for self-fulfillment for individuals. Such a transformation inside the movement is consistent with the theory of "group identities" developed by Manuel Castels. The Spanish sociologist argues that in the network society of our times, group identities are based most of all on group resistance and only afterwards they can transform into project identities. In this particular example, such a transformation may have been fostered by the emergence of several other points of resistance in the world, inspired by the Spanish movement. Nevertheless, the durability of 15-M's group identity will depend on its ability to influence the current domestic politics.

Interestingly, the Spanish indignados seem to embody many transformations typical for modern societies, defined by Anthony Giddens as a passage towards the "late modernity". Their demands are in many respects convergent with the program of "life politics", described by this British sociologist. The passage towards the late modernity is also visible in the global reach of their protests. On one hand, they raise the issue of global processes haveing local effects. On the other hand, their protests have a clearly expansionary nature. With the emergence of several other groups of indignados, for example in United States or in Chile, the 15-M may become an avant-garde of a wider global movement. At the same time, it has become clear that, regardless of a particular economic, political and social context which undoubtedly served as a catalyst for social unrest in Spain, the identity of the 15-M movement is based strongly on universal values, going far beyond the domestic context.

\section{Le mouvement espagnol 15-M: une identité-projet à l'état naissant}

Le mouvement espagnol 15-M est devenu un point de référence pour tous les «indignés» qui ont organisé des manifestations dans les régions reculées du monde. Pour cette raison, le phénomène de 15-M fait un objet d'intérêt pour les sociologues, politologues et journalistes espagnols et étrangers. Dans cet article, nous faisons le premier pas afin de comprendre le mouvement 15-M et dessayer de déterminer son identité collective.

Notre analyse souligne le caractère évolutif du mouvement. Au début il était plutôt chaotique et incohérent, mais au fil du temps, il a commencé à se définir par plusieurs caractéristiques, telles que: la dominance des jeunes, l'indifférence politique, le pacifisme et l'utilisation de nouvelles technologies. En outre, au début le mouvement a été basé sur le mécontenement collectif et la résistance, mais 
finalement il est devenu un défenseur d'un changement social particulier. Cette transformation sociale s'exprime par le développement de la démocratie participative, la soumission du capitalisme international et la garantie de la justice sociale et des conditions adéquates pour la réalisation de soi. Une telle transformation au sein du mouvement est conforme à la théorie des «identités collectives» développée par Manuel Castells. Ce sociologue espagnol fait valoir que de nos jours, dans la société en réseaux, les identités collectives sont basées principalement sur la résistance du groupe et que par la suite, elles peuvent se transformer en identitésprojets. Dans cet exemple particulier, une telle transformation peut être favorisée par l'émergence de plusieurs autres points de résistance dans le monde, inspirés par le mouvement espagnol. Néanmoins, la pérennité de l'identité du groupe de 15-M dépendra de sa capacité à influencer les politiques actuelles domestiques.

Les indignés espagnols semblent incarner les changements caractéristiques de nombreuses sociétés modernes, définis par Anthony Giddens comme un pas vers la «modernité tardive». Leurs demandes sont à bien des égards convergentes avec le programme de la "politique de la vie» décrit par le sociologue britannique. Le passage vers la modernité tardive est également visible dans la portée globale de leurs protestations. D'une part, ils soulèvent la question des processus globaux ayant des effets locaux. D'autre part, leurs manifestations ont un caractère clairement expansionniste. Avec l'émergence de plusieurs autres groupes d'indignés, par exemple aux Etats-Unis ou au Chili, le 15-M peut devenir une avant-garde d'un vaste mouvement mondial. Dans le même temps, il est clair que, indépendamment d'un particulier contexte économique, politique et social, qui a sans doute servi de catalyseur aux manifestations en Espagne, l'identité du mouvement 15-M est fortement basée sur des valeurs universelles, allant bien au-delà du contexte national. 